\title{
Analisis Kritis Wacana Poligami: Praktik Marjinalisasi dan Demonologi Islam dalam Wacana Poligami
}

\author{
Ema Khotimah
}

ABSTRACT

Polygamy (and also anti-polygamy) always become hot issue in Indonesia. There are at least two national events which reintroduced polygamy discourse: the second-marriage of famous religious leader-KH Abdullah Gymnastiar, and pornographic video depicting sexual relationship between Yahya Zaini-a high political figure - and Maria Eva - a wannabe celebrity. A strong and emotional debate over those two events marginalized the main issue of polygamy itself in the world of Islam. A critical discourse analysis toward polygamy discourse has found that marginalization practices are conducted even by prominent members of Islamic organizations and intellectuals, as well as members of legislative body. It turned out that polygamy discourse was biased and misrepresented.

Kata kunci: poligami, marjinalisasi, misrepresentasi, bias wacana.

\section{Pendahuluan}

\subsection{Latar Belakang}

Di akhir 2006, terjadi dua peristiwa yang "menghebohkan" khalayak media di negeri ini. Pertama, keputusan da'i kondang Abdullah Gymnastiar yang terkenal dengan panggilan Aa Gym untuk berpoligami. Kedua, tersebarnya video porno antara tokoh politik YZ dan penyanyi dangdut ME. Ironisnya, fenomena perselingkuhan yang jelas-jelas bertentangan dengan syariat Islam dalam hal mendekati zina dan zina. Khalayak menanggapinya dengan "adem-adem" saja alias memandang fenomena itu sebagai hal yang lumrah. Namun, fenomena poligami serta merta dihujat, dibenci, ditentang, dan ditolak dalam kehidupan sosial budaya masyarakat kita. Barangkali tepat apa yang dikatakan oleh Hartono:
Dari kalangan liberal dan penyeru feminisme dengan poligaminya Aa Gym, mereka seolah mendapat momentum untuk memobilisasi kaum Hawa guna menolak syariat poligami dengan teriakan sekeraskerasnya. Lebih-lebih, mereka mendapat dukungan media yang lumayan banyak dan kompak. Ironisnya, mereka juga memaki dalil-dalil Al-Qur'an dan hadist-hadist serampangan. Mereka memahaminya dari perspektif Marxisme dan gender equality yang bersemangat 'dendam' terhadap laki-laki.....Anehnya, fenomena perselingkuhan yang merendahkan wanita, di mana wanita hanya dijadikan pemuas nafsu seksual semata dan dibiarkan menggugurkan kandungannya, sebagaimana dialami penyanyi dangdut ME, orang-orang yang berbaju liberal dan mengaku pembela hak wanita itu malah diam saja. Yang dinikahi secara resmi dipersoalkan, namun yang dijadikan teman perselingkuhan justru didiamkan (2007: x-xi). 
Memang, pasca - ‘terkuaknya' pernikahan Aa Gym dengan Alfarini Eridani, janda tiga anak dan mantan model ini sebagai istri kedua pada bulan Oktober 2006, seakan mengundang genderang 'perang' dari kalangan penentang poligami untuk mengusung agendanya di media massa. Jurus "agenda setting" media juga telah mampu menggiring publik ke dalam perbincangan serupa khalayak di semua lapisan masyarakat, terutama kaum perempuan, sibuk membincangkan "poligami Aa Gym", tentu dengan keragaman pemikiran. Bahkan, Presiden pun secara khusus membahas wacana poligami ini dengan Menteri Negara Pemberdayaan Perempuan, Meutia Hatta dalam upaya merespon sejumlah pendapat yang berkembang di masyarakat dalam perihal poligami.

Dalam diskursus di media elektronik, terlebih pasca Presiden dan Menteri Negara Pemberdayaan Perempuan turun tangan merespons masalah poligami. Agenda media massa, terutama media elektronik seakan memperkuat wacana dominan yang kontra poligami. Ini sebenarnya juga menunjukkan ketidakpastian masyarakat kita yang mayoritas Muslim terhadap isu-isu semacam itu. Fenomena penentangan dan penolakan poligami oleh sebagian besar masyarakat di Indonesia, terutama kaum perempuan, juga menunjukkan fenomena ketidakpastian dan resistensi masyarakat di Indonesia dalam merealisasikan ajaran Islam. Sebagai contoh, masih banyak masyarakat yang menganggap bahwa poligami itu tidak ada dalam Islam.

Ada perbedaan antara pelaksanaan Islam secara formal dan legal dengan pelaksanaan Islam secara komprehensif dan substansial. Perbedaannya barangkali adalah pada level membangun kesadaran dan kesiapan masyarakat. Sebab, masyarakat yang berada dalam kawasan formalisasi syariat tanpa sosialisasi maksimal dan menyeluruh akan merasa "terpaksa" untuk mengamalkan semua ajaran Islam. Sementara, masyarakat yang berada dalam kawasan syariat Islam secara substansial bisa menerima semua ajaran Islam yang dianggap oleh mereka yang tidak setuju sebagaimana halnya dalam wacana poligami atau wacana berjilbab.
Persoalan perempuan sendiri, baik dari sudut pandang emosional maupun sosial, sampai saat ini pun masih merupakan topik perdebatan yang tak ada habis-habisnya. Karena ilmu pengetahuan gagal menawarkan pemecahan memuaskan, maka suka atau tidak suka, persoalan ini akan tetap memiliki warna ideologis yang kental. Syariati (200:12) menulis, "seperti persoalan-persoalan lainnya yang masih belum mampu dijawab secara memuaskan oleh para peneliti dan ilmuwan, maka isu perempuan ini pun akan tetap menjadi pekerjaan rumah kalangan filsuf, agamawan, ahli adat-istiadat, pemerhati tren zaman, dan konteks tuntutan sosial dan individual suatu zaman untuk menafsirkan dan menguraikannya.

Isu poligami merupakan contoh yang sangat jelas dalam hal ini. Pada zaman sekarang, praktik poligami dianggap sebagai suatu bentuk kejahatan tersembunyi terhadap perempuan. Akan tetapi, di masa lalu praktik poligami telah memungkinkan para janda dan anak-anaknya yang telah kehilangan ayah untuk menikmati kehangatan, rasa aman, dan kesejahteraan dalam sebuah keluarga utuh.

Sebagaimana halnya yang terjadi pada isu jilbab (hijab) atau busana Muslim. Di zaman sekarang, busana ini dianggap sebagai pembatas gerak dan kebebasan perempuan. Para pemikir kontemporer menganggap sebagai keanehan dan model "menggelikan". Namun, di masa lalu, cadar dan jilbab merupakan simbol kelompok elite, ukuran gengsi sosial, dan semacam bentuk "pemeliharaan martabat dan kehormatan perempuan" (Syariati, 2004:15). Bahkan, sampai saat ini, pada lapisan masyarakat pedesaan atau masyarakat perkotaan tertentu yang masih setia pada tradisi cadar dan jilbab, masih memiliki status yang sama, demikian pula halnya sistem perkawinan poligami.

Lantas, muncul sejumlah pertanyaan berkenaan dengan wacana dominan, yang saat ini berkembang di Indonesia, yaitu penentangan sistem perkawinan poligami terus wacana dominan. Dalam diskursus media elektronik selama Desember 2006, terlebih pasca-Presiden dan Menteri Pemberdayaan Perempuan melakukan upaya membatasi, bahkan mengancam pelaku poligami dan pihak-pihak yang terlibat dalam 
praktik poligami melalui jerat pasal-pasal pidana, semakin memperkuat wacana dominan yang menentang poligami dan mengukuhkan persepsi yang berkembang di masyarakat yang memang anti-poligami.

Ada dua konsekuensi dari wacana dominan tersebut. Pertama, wacana dominan memberikan arah bagaimana suatu objek harus dibaca dan dipahami. Oleh karenanya, pandangan yang bertentangan menjadi tersudutkan, karena wacana ini memberikan pilihan yang tersedia dan siap pakai. Kedua, struktur diskursif yang tercipta atas suatu objek, tidaklah berarti kebenaran. Pada dasarnya, kekuasaan selalu memroduksi suatu politik kebenaran tertentu yang dengannya dominasi dimapankan, disusun, dan dilestarikan.

Dalam wacana poligami, praktik marginalisasi ini tampak jelas salah satunya dalam pemilihan narasumber ideologi feminis bagi pihak penentang poligami. Sebaliknya, bagi yang pro poligami, kaum Islam ideologis pun ikut terlibat dalam proses diskursus dengan mengetengahkan beberapa narasumber yang handal. Strategi kaum penentang poligami dalam memarjinalkan poligami pun dilakukan, mulai dari strategi pengasaran (disfemisme), penjulukan (labelling), sampai kepada stereotip yang negatif yang dituduhkan bagi praktik dan pelaku poligami.

Berbekal atas sikap keprihatinan atas marjinalisasi wacana poligami dalam diskursus sosial budaya dan politik di Indonesia, maka praktik wacana di media pun menjadi urgen untuk diteliti.

\subsection{Perumusan Masalah}

(1) Bagaimana praktik marjinalisasi berlangsung atas wacana poligami di media massa?

(2) Agenda apa yang sesungguhnya 'diusung' dalam wacana anti-poligami?

\section{Tinjauan Pustaka}

\subsection{Menuju Ke Pemahaman Wacana}

Paul Racouer (2002: 30) berujar, "bermula dari distingsi Saussure antara langue dan parole, kita dapat mengatakan, setidaknya pada tahap pengenalan bahwa wacana merupakan peristiwa bahasa”. Aspek penting dari wacana, menurutnya adalah bahwa wacana dialamatkan atau diarahkan kepada seseorang. Sementara itu, Faucoult (dalam Eriyanto, 2002:65) mendeskripsikan wacana di media massa tidak hanya berupa rangkaian kata-kata atau proporsi dalam teks, tetapi lebih kepada sesuatu yang memroduksi yang lain (sebuah gagasan, konsep, atau efek).

Secara lebih terinci Alex Sobur menggambarkan wacana dalam berbagai aspek makna kebahasaan. Kata discourse, jelasnya berasal dari bahasa latin discursus yang berarti lari kian kemari (yang diturunkan dari dis-dari dalam arah yang berbeda dan currere "lari"). Beberapa pengertian yang lebih mendasar tentang wacana meliputi :

(1) Komunikasi pikiran dengan kata-kata, ekspresi, ide-ide atau gagasan-gagasan konversasi atau percakapan.

(2) Komunikasi secara umum, terutama sebagai suatu subyek studi atau pokok telaah.

(3) Risalat tulis, disertasi formal, kuliah, ceramah; khotbah (Webster, 1983 : 522, dalam Sobur, 2001:9-10).

Sementara itu, Teun A. van Dijk mengemukakan bahwa begitu sulitnya discourse dirumuskan karena akan melibatkan berbagai faktor yang bersifat kompleks sebagaimana dituturkannya:

It would be nice if we could squeeze all we know about discourse into a handy definition, Unfortunately, as is also the case for such related concepts as "language", "communication", "interaction", 'society', and 'culture', the notion of discourse is essentially fuzzy. As is so often the case for consepts that stand for complex phenomena (1997:1).

Para analis wacana juga berusaha merumuskan definisi umum wacana. Umumnya, mereka sepakat bahwa wacana merupakan suatu bentuk penggunaan bahasa. Satu karakteristik yang khas yang menandai wacana adalah pada aspek fungsionalnya berupa peristiwa komunikasi. Tempat dimana orang menggunakan bahasa untuk mengomunikasikan ide-ide, kepercayaankepercayaan atau ekspresi-ekspresi mereka, dalam peristiwa sosial yang kompleks, misalnya dalam 
suatu situasi tertentu seperti saat menelepon, bertemu teman, belajar di kelas, wawancara pekerjaan, waktu kunjungan ke dokter, atau saat menulis atau membaca laporan berita, begitu menurut pemaparan van Dijk secara lengkap.

Melalui pendekatan ini, rumusan wacana menurut van Dijk pada dasarnya mengandung tiga dimensi utama:

(1) language use

(2) the communication of beliefs (cognition)

(3) interaction in social situation (1997:2).

\subsection{Teks, Konteks, dan Wacana}

Bila teks merujuk pada wujud konkret penggunaan bahasa berupa untaian kalimat yang mengemban proposisi-proposisi tertentu sebagai suatu keutuhan. Menurut Fowler (1986) dalam Aminuddin , wacana tentu saja berbeda dengan teks, sebab wacana menunjuk pada kompleksitas aspek yang terbentuk oleh interaksi antara aspek kebahasan sebagaimana terwujud dalam teks dengan aspek luar bahasa. Interaksi tersebut selain menentukan karakteristik bentuk komunikasi atupun penggunaan bahasanya, juga berfungsi dalam menentukan makna suatu teks (dalam Aminuddin dkk, 2002 : 37). Unsur yang dimaksud Fowler, yang berada di luar bahasa tersebut merujuk kepada pemeran/partisipan atau peserta komunikasi, tujuan, dan konteks. Dalam perspektif kajian linguistik secara kritis, konteks tersebut meliputi konteks ujaran, konteks kebudayaan, dan konteks referensi .

Ada enam konsep utama teks dalam pandangan Van Dijk (2003:2), yaitu :

(1) Suatu teks adalah suatu entitas yang dirangkum dalam suatu topik.

(2) Beberapa teks (atau beberapa rangkaian sub topik) merupakan suatu wilayah pengertian yang secara hierarkis diorganisir, mulai dari tingkat permukaan sampai kedalaman dan sampai pada sub topik yang lebih umum.

(3) Tingkat luaran (permukaan) suatu teks terdiri atas kata-kata (atau simbol-simbol) yang sebenarnya merupakan rangkaian ungkapan.

(4) Tingkat permukaan secara berurut dapat dianalisis secara logis guna menunjukkan struktur logis atau hubungan linier dan koherensi linier.

(5) Tidak ada satu pun teks yang secara utuh dipahami secara sederhana melalui analisis logis struktur urutan linier, karena semua relasi logis antar proposisi tidak pernah sepenuhnya terklarifikasi berdasarkan bukti-bukti simbolik.

(6) Kadang-kadang apa yang dikatakan (secara simbolik ditunjukkan) pada tingkat permukaan (luaran) memberi kita pemahaman apa yang terdapat pada tingkat yang lebih dalam seperti yang tampak pada teks.

Oleh karena itu, benar apa yang dikatakan oleh Guy Cook bahwa antara teks, konteks, dan wacana merupakan satu kesatuan yang tak terpisahkan (dalam Sobur, 2001:56). Sejalan dengan Fowler, Cook juga dalam kalimat yang berbeda merumuskan hal yang sama menurutnya:

(1) Teks merupakan semua bentuk bahasa baik itu kata-kata yang tercetak di kertas, tetapi juga termasuk ke dalamnya berbagai ekspresi komunikasi, seperti ucapan, musik, gambar, efek suara, citra, dan lain-lain.

(2) Konteks, terdiri atas semua situasi yang berada di luar teks dan memengaruhi pemakaian bahasa, seperti partisipan, situasi, fungsi, dan lain-lain.

(3) Wacana, menurutnya, adalah teks dan konteks sebagai satu kesatuan.

Oleh karena itu, Cook menggarisbawahi analisis wacana adalah upaya menggambarkan teks dan konteks secara bersama-sama dalam proses komunikasi, sehingga, menurut Alex Sobur, adalah sebuah konsekuensi logis bila arti atau makna dari sebuah kalimat sebenarnya barulah dapat dikatakan benar bila kita ketahui siapa pembicaranya, siapa pendengarnya bila diucapkan, dan lain-lain. Oleh sebab itulah maka ahli analisis wacana menganalisis kalimat-kalimat itu dengan menganalisis konteksnya terlebih dahulu (2001:56).

Berbicara masalah konteks, Fillmore, sebagaimana dikutip oleh Alex Sobur (2001:56), mengemukakan betapa pentingnya bahasan konteks dalam wacana, sebab konteks itu menentukan makna suatu ujaran. Bila konteks berubah, maka berubah pulalah maknanya. Pada 
Terakreditasi Dirjen Dikti SK No. 56/DIKTI/Kep/2005

dasarnya, konteks pemakaian bahasa dapat dibedakan ke dalam empat jenis kategori yaitu :

(1) Konteks fisik (physical context) meliputi tempat terjadinya pemakaian bahasa dalam suatu komunikasi, objek yang disajikan dalam peristiwa komunikasi itu, dan tindakan atau perilaku dari para peran dalam komunikasi itu.

(2) Konteks epistemis (epistemic context) latar belakang pengetahuan yang sama-sama diketahui oleh pembicara maupun pendengar.

(3) Konteks linguistik (linguistic context) terdiri atas kalimat-kalimat atau tuturan-tuturan yang mendahului satu kalimat atau tuturan-tuturan tertentu dalam peristiwa komunikasi.

(4) Konteks sosial (social context) relasi sosial dan latar setting yang melengkapi hubungan antara pembicara (penutur) dengan pendengar (Salafi'ie dalam Sobur, 2001:57).

Begitu juga menurut van Dijk (1997) dalam membahas discourse (wacana) sebagai aksi dan interaksi, konteks merupakan hal yang sangat krusial. Tetapi, yang paling krusial di antara unsurunsur konteks adalah para peserta yang terlibat di dalam wacana. Unsur-unsur yang terlibat dalam konteks, selain partisipan, adalah setting, perangkat keras, tindakan, pengetahuan dan kesengajaan, tindakan-tindakan dalam level yang lebih tinggi, lokal atau global konteks, konstruksi konteks.

Secara intuitif, tindakan merupakan suatu yang dilakukan orang, seperti jatuh dari tangga, bermimpi atau melihat sesuatu tegasnya, di dalam berbagai situasi secara sosial, secara moral, dan secara hukum dikatakan bertindak, sekalipun kita seolah tidak melakukan sesuatu seperti pada saat kita terdiam, duduk berdiam diri atau duduk sambil merokok. Kecenderungan-kecenderungan tindakan yang dilakukan oleh manusia ini sepanjang mengandung unsur "kesengajaan" (intentional), menurut van Dijk, disebut tindakan.

Maka itu, van Dijk secara tegas menyebut wacana sebagai suatu bentuk tindakan. Karena wacana pada umumnya mengandung unsur kesengajaan, terkontrol, dan mengandung maksud tertentu, artinya manusia pada umumnya tidak hanya secara kebetulan atau tanpa sengaja berbicara, menulis, membaca, atau mendengarkan. Kalaupun itu terjadi, misalnya berbicara saat tidur atau dihipnotis, ini adalah perkecualian, karena kita tidak akan dimintai pertanggungjawaban untuk kedua kasus ini. Selain itu, dalam wacana juga akan melibatkan berbagai perspektif lainnya seperti perspektif dari peserta yang terlibat di dalam wacana itu. Wacana juga sebagai bentuk tindakan akan menghasilkan implikasi-implikasi tertentu kepada pihak penerima, konsekuensi-konsekuensi juga akan muncul akibat wacana yang mengemuka dalam konteks sosial masyarakat.

\subsection{Wacana dan Media Massa}

Media sudah sekian lama melibatkan fokus kerja bahasa dan komunikasi pada praktiknya, ini juga yang terjadi bertahun-tahun dalam studi media. Wacana sebagai praktik sosial yang melibatkan kerja bahasa dan komunikasi di media massa pun menjadi pusat perhatian para ahli ini, menurut Allan Bell, karena beberapa alasan sebagai berikut :

(1) Media kaya akan sumber data yang dapat diakses untuk riset dan pengajaran.

(2) Media menggunakan kata-kata yang dipengaruhi dan merepsentasikan penggunaannya juga mengungkapkan sikapsikap dalam bahasa ujaran komunitas tersebut.

(3) Media dapat menginformasikan makna-makna sosial dan stereotip-stereotip pada bahasa dan komunikasi.

(4) Media merefleksikan dan memengaruhi formasi dan ekspresi budaya, politik dan kehidupan sosial (1998:3).

Bahasa bagaimanapun merupakan alat komunikasi yang netral dan kosong dalam dirinya sendiri, hampir sama dengan media yang hanya berisi jika di isi pesan oleh pemakaiannya kepada pihak tertentu (Sobur, 2001 : 33), sehingga makna bukanlah sesuatu yang melekat pada kata atau bahasa, tetapi makna ada pada orang (subjek) yang dikarenakan, sebagaimana sering diungkapkan bahwa "word don't mean, people means". Makanya kemudian dalam konteks wacana, makna begitu penting, sebab sebagaimana diungkapkan Hall (1982) makna adalah sebuah pertentangan 
sosial (social struggle), sebuah perjuangan dalam memenangkan wacana. Pada konteks inilah berawalnya perebutan wacana dan proses hegemoni atas wacana, saat wacana dikuasai oleh pihak-pihak dominan yang memarjinalkan pihak terdominasi.

Inilah yang menyebabkan media banyak disebut sebagai sarana mediator dalam konteks politik pemaknaan. Mengapa demikian? karena melalui hegemoni wacananya, media melakukan definisi-definisi atas realitas sosial, politik, dan kultural yang ada di masyarakat sebagaimana dikatakan Edward W., peristiwa bahasa (wacana) dalam konteks media massa tidak hanya menggambarkan, tetapi juga mendefinisikan sebuah realitas politik" (2002). Kecenderungan orientasi yang sama juga diungkapkan oleh Deddy Mulyana dengan merujuk kepada Peter D. Moss (1999), bahwa:

Wacana media massa, termasuk berita surat kabar, merupakan konstruk kultural yang dihasilkan ideologi, karena sebagai produk media massa, berita surat kabar menggunakan kerangka tertentu untuk memahami realitas sosial. Lewat narasinya, surat kabar menawarkan definisi-definisi tertentu mengenai kehidupan manusia, siapa pahlawan dan siapa penjahat, apa yang baik dan apa yang buruk bagi rakyat : apa yang layak dan apa yang tidak layak untuk dilakukan seorang pemimpin, tindakan apa yang disebut perjuangan (demi membela kebenaran dan keadilan) dan pemberontakan atau terorisme, isu apa yang relevan dan tidak ..... (dalam Eriyanto, $2002: \mathrm{x}$ ).

\section{Pembahasan}

\subsection{Marjinalisasi Poligami}

Pemberitaan perihal Aa Gym berpoligami; tidak hanya di media massa. Media pun dalam hal ini telah mampu menggiring khalayak ke dalam topik yang sama. Khalayak di semua lapisan masyarakat sibuk membahas "poligami-nya Aa Gym”, tentu dengan keragaman pemikirannya. Bahkan, wacana ini pun sampai "mendorong" presiden untuk secara khusus membahasnya dengan Menteri Negara Pemberdayaan Perempuan, Meutia Hatta.

Dalam diskursus di media elektronik, terlebih pasca Presiden Susilo Bambang Yudhoyono menginstruksikan revisi undang-undang perkawinan kepada Menteri Negara Pemberdayaan Perempuan untuk lebih membatasi poligami dan menetapkan sanksi bagi pelanggarnya, maka wacana tentang anti-poligami pun "dilanggengkan" dengan berbagai argumen yang melekat pada praktik dan wacana tersebut. Argumen-argumen tersebut, di antaranya, adalah bahwa poligami merupakan penyebab kekerasan dalam rumah tangga, sumber penyebaran penyakit, diskriminasi terhadap perempuan, penindasan terhadap perempuan. Oleh karena itu, negara dalam hal ini mengambil tempat sebagai institusi pelindung perempuan seperti dikatakan Faucoult, "kuasa tidak bekerja melalui penindasan dan represi, tetapi melalui normalisasi dan regulasi publik dalam hal ini tidak dikontrol lewat kekuasaan yang sifatnya fisik, tetapi dikontrol, diatur, dan disiplinkan lewat wacana (dalam Eriyanto, 2001:67)

Dalam diskursus sosial budaya dan politik di Indonesia, sejak ditetapkannya Undang-undang No. $1 / 1977$ dan PP No. 10/1983, tentang Aturan Berpoligami, telah menempatkan poligami ke dalam wacana yang termarjinalkan. Bagaimana tidak. Aturan yang bernuansa politis itu telah mewadahi suara mayoritas yang menentang praktik poligami. Dampak dibalik pemberlakuan Peraturan Pemerintah itu adalah pandangan yang negatif terhadap praktik poligami dari masa ke masa. Bahkan, para pelakunya harus siap dengan stigma sosial yang kerap harus diterima dalam kehidupan sosialnya sebagai konsekuensi logis berpoligami. Stigma dan julukan-julukan "tukang kawin," "perebut suami orang," adalah julukan yang lazim diterima pelaku poligami.

Ada dua konsekuensi dari wacana dominan tersebut. Pertama, wacana dominan memberikan arah bagaimana suatu objek harus dibaca dan dipahami. Pandangan yang lebih luas terhalang, karena ia memberikan pilihan yang tersedia dan siap pakai. Pandangan dibatasi hanya dalam batasbatas struktur diskursif tersebut, tidak dengan yang lain. Kedua, Struktur diskursif yang tercipta atas suatu objek tidaklah berarti kebenaran. Batas-batas yang tercipta tersebut bukan hanya membatasi 
pandangan kita, tetapi juga menyebabkan wacana lain yang tidak dominan, menjadi terpinggirkan. (Aditjondro dalam Eriyanto, 2001:77)

Meski demikian, menurut George Yunus Aditjondro, adalah lazim dalam suatu masyarakat terdapat berbagai pandangan yang bebeda satu dengan yang lainnya. Namun, dalam diskursus wacana demikian kekuasaan akan memilih dan mendukung wacana tertentu, sehingga wacana lainnya akan "terpinggirkan" (marginalized) atau "terpendam" (sub merged).

Lalu, bagaimana praktik marginalisasi dalam wacana poligami ini berlangsung di media massa? Proses marginalisasi di media massa terjadi melalui bahasa. Pemilihan kata, kalimat, proposisi, oleh nara sumber, menurut Fowler, "bukan semata persoalan linguistik, tetapi ekspresi ideologi (dalam Eriyanto, 2001). Melalui pilihan linguistik, wacana dominan mampu menggiring opini publik, meneguhkan dan melakukan justifkasi pandangannya atas wacana dominan dan ideologi yang diusungnya dengan mengucilkan dan menyerang pihak lain.

Dalam wacana poligami, praktek marjinalisasi ini tampak jelas. Narasumber berbasis ideologi feminisme dan liberalisme memilih strategi linguistik tertentu mulai disfemisme, labelisasi, hingga stereotipe. Jika praktik eufemisme berupa penghalusan kata atau ungkapan dalam memaknai realitas, maka disfemisme justru sebaliknya menggunakan teknik pengasaran atas realitas. Sebut misalnya, Ade Armando, yang tergabung dalam diskusi di jaringan Islam Liberal menyebut poligami dengan sebutan," beristri lebih dari satu di zaman ini adalah najis! sikap saya - dan saya yakin banyak orang lain - soal poligami adalah sama dengan dikap saya soal perbudakan" (dalam Hartono, 2007 : 168).

Kata "najis" dan "perbudakan" mengandung pengasaran dari realitas sesungguhnya atas praktik poligami. Argumennya adalah bila memang poligami merupakan perbuatan itu 'najis', maka kenapa Islam membolehkannya? Kalau memang 'najis', mengapa Islam tidak mengharamkannya sebagaimana Islam mengharamkan minuman keras dan daging babi? Jika praktik poligami merupakan praktik 'perbudakan', dengan demikian gugurlah argumen bahwa "Islam menilai diskriminasi sebagai kejahatan “ (Syariati, 2004:17). Dengan kata lain, argumen ini juga menuduh Islam adalah ajaran yang melanggengkan 'perbudakan' dengan menghalalkan poligami.

Praktik marjinalisasi juga dilakukan melalui bahasa dalam bentuk labelisasi dan stereotip. Misalnya, ungkapan Mira dari Komnas HAM perempuan di salah satu debat tentang poligami di SCTV acara "TOPIK" tanggal 6 Desember 2006 menggunakan kalimat-kalimat berikut ini:

- "Perlu upaya mengatur korban-korban poligami"

- "Pejabat publik tidak mengubar syahwat."

Musdah Mulia dari kalangan Islam Reformis, pada kesempatan yang sama menggunakan kalimat "Poligami selalu alasannya syahwat." Meutia Hatta menegaskan, "banyak kaum perempuan diperlakukan tidak adil dalam perkawinan dan ini memicu keprihatinan". Kemudian, MM Billah dari Komnas HAM menyebutnya sebagai, "Poligami ekspresi hubungan tidak setara di antara laki-laki dan perempuan dan ini bertentangan dengan HAM." Bahkan, salah seorang ustad-ustad muda di salah satu tayangan infotainment, menyebut Aa Gym sebagai pelaku poligami tengah "kepeleset" alias “ khilaf', atau dengan kata lain Aa Gym sedang menjadi "pendosa" atau melakukan "kesalahan". Inilah stigma yang kerap memang ditimpakan kepada pelaku poligami di Indonesia.

Strategi serupa dikembangkan kaum orientaslis Barat dalam diskusus poligami. Mereka dengan tegas menggunakan argumen bahwa kehidupan rumah tangga dengan beberapa istri dari seorang pria hanya pemborosan materi saja, kejahatan tersembunyi, dan penindasan terhadap hak-hak wanita. Kata-kata seperti pemborosan, penindasan, kejahatan tersembunyi, dan stereotip di sini merupakan praktek presentasi yang menggambarkan poligami penuh prasangka konotasi negatif dan bersifat subjektif.

\subsection{Demonologi dan Kekeliruan Pandangan atas Wacana Poligami}

Sebenarnya, pencitraan atas Islam dalam 
wacana poligami sudah lama berlangsung. Nabi Muhammad saw sendiri di media Barat kerap dicitrakan sebagai "si maniak seks", "don juan" dan "sang teroris." Perusahaan kartun a Dooug Marlatte, misalnya, membuat headline "What would Mohammed Drive?" digambarkan Rasulullah mengendarai truk berisi bom yang mirip sekali dengan truk yang digunakan Timothy Veigh dalam pemboman di Oklahoma City, tahun 1995. Sindiran dan tuduhan sebagai teroris dan pengumbar syahwat pun baru-baru ini dilakukan oleh media Barat melalui kartunis Denmark yang menggambarkan Rasulullah dengan pedang terhubus didampingi dua wanita.

Lalu apa sesungguhnya yang terjadi pada masyarakat kita saat poligami menjadi wacana yang dihujat, ditentang, sementara wacana "selingkuh" malah disebut-sebut sebagi perbuatan yang "indah"? Bahkan, di Inggris, Belanda dan Amerika, homoseksual dihalalkan, sementara poligami dilarang. Sama halnya dalam wacana terorisme, dalam wacana poligami pun telah sampai pada proses "demonologi Islam" (penghantuan Islam) melalui pencitraan negatif wacana poligami. Anwar Al Jundy menyebutnya sebagai "pembaratan di dunia Islam." Menurutnya, pembaratan dalam pengertian yang paling luas berarti mendorong kaum Muslim menerima pemikiran-pemikiran Barat, sehingga mereka tumbuh dalam kehidupan dan pemikiran Barat dan nilai-nilai ke-islaman menjadi kering dalam jiwa mereka. Media massa dalam hal ini telah menjadi sarana yang "powerfull” dalam demonologi Islam dan demoralisasi, khususnya melalui kampanye free sex dan pornografi.

Demonologi ini cukup "powerfull” dalam menggiring khalayak dalam penghantuan bahkan sampai pada phobia terhadap Islam (Islamophobia). Terbukti, pascapoligaminya Aa Gym, para jamaah yang sudah merencanakan kunjungan ke Pesantren Da'arut Tauhid, nyaris semuanya membatalkan. Bahkan, yang sudah memesan akomodasi dan transportasi kepada pihak agen travel pun membatalkan kedatangannya. Perlahan tapi pasti, Pesatren Daarut Tauhid ditinggalkan umatnya karena pimpinan pondok pesantren itu berpoligami. Sekarang yang bertahan mengunjungi pondok pesatren tersebut masih ada, namun sebagaimana diberitakan di media massa, jumlahnya berkurang sangat signifikan. Bahkan, yang biasanya malam Jum'at sepulang dan waktu keberangkatan para pengunjung pesatren untuk menghadiri pengajian rutin selalu menyebabkan kemacetan. Sekarang kemacetan itu tidak pernah terjadi lagi akibat hal serupa.

Bahkan, yang tidak kalah 'mengenaskan' adalah yang dulunya pengunjung setia Daarut Tauhid, serta-merta setelah peristiwa itu ikut "ramerame" menghujat Aa Gym di media massa. Foto Aa Gym disobek oleh sejumlah jamaah setianya yang, tentu saja, mayoritas kaum perempuan.

Jika alasan kaum penentang poligami karena ingin melindungi kaum perempuan. Maka, sebenarnya negara ini telah bertahun-tahun mengeksploitasi kaum perempuan tanpa perlindungan hukum saat permepuan-perempuan Indonesia dikirim menjadi TKW yang notabene menjadi sumber devisa semata. Lalu, jika poligami dituduh penyebab keresahan masyarakat, apakah kaum yang menentang poligami mampu memberikan solusi atas berbagai masalah sosial yang terjadi di masyarakat kita saat ini, seperti halnya perzinaan melalui perselingkuhan dan prostitusi, yang merupakan wujud nyata kejahatan laki-laki dan perempuan.

Barangkali tulisan Gustave Le Bon di dalam bukunya La Civilization des Arabs, sebagaimana ditulis ulang Murtadha Muthahhari, relevan dengan demonologi Islam dalam wacana poligami.

Tidak ada, menurutnya, kebiasaan yang lebih dihina dan dimana lebih banyak gagasan keliru dikemukakan, daripada poligami. Bagi para sejarawan yang paling serius, poligami telah dianggap ujung tombak Islam, sebab utama penyebaran Al-Qur'an dan pada saat yang sama, sebab keruntuhan dunia Timur. Penegasanpenegasan yang ganjil ini pada umumnya diikuti dengan semburan kemarahan atas nasib yang malang dari kaum wanita yang sengsara yang terkurung disudut-sudut harem, yang dijaga oleh orang-orang kasim yang galak, dan dibunuh tanpa belas kasihan apabila mereka tidak lagi 
Terakreditasi Dirjen Dikti SK No. 56/DIKTI/Kep/2005

menyenangkan tuannya.

Gambaran semacam ini bertentangan dengan kebenaran. Pembanca yang hendak membaca bab ini dengan mengenyampingkan prasangka Eropanya, saya harap, akan menjadi yakin bahwa poligami Timur adalah suatu lembaga yang cemerlang yang sangat mengangkat standar moral orang-orang yang mempraktikkannya, memberikan stabilitas yang besar kepada keluarga, dan, terakhir, membuat wanita lebih terhormat dan lebih bahagia ketimbang di Eropa.

Sebelum mengemukakan bukti tentang hal ini, pertama-tama saya akan mengingatkan bahwa poligami sama sekali tidak tergantung pada Islam, karena ia sudah terdapat sebelum Muhammad di kalangan bangsa Timur: Yahudi, Persia, Arab, dan sebagainya. Karenanya, bangsa-bangsa yang telah menerima Al-Qur'an tidaklah mendapatkan keuntungan apa-apa dengan menerima poligami. Bagaimanapun juga, belum pernah ada suatu agama yang cukup kuat untuk menstransformasikan tradisi-tradisi sampai kepada titik menciptakan atau mencegah suatu lembaga semacam itu. Poligami hanyalah akibat dari suatu iklim, ras, dan kondisi-kondisi lainnya dari kehidupan yang khas bagi orang-orang timur ....

Di Barat, di mana iklim dan temperamennya jauh lebih tidak menuntut, monogami tidak lagi terdapat, kecuali dalam undang-undang, dan tak seorang pun akan menyangkal, saya kira, bahwa monogami sangat jarang terdapat dalam perilaku orang. Saya tidak mengerti dalam hal poligami yang legal di kalangan orang Timur dipandang lebih buruk dari poligami hipokrit di kalangan orang Barat. Sebaliknya, saya malah dapat melihat dengan jelas dalam hal apa poligami Timur itu lebih baik. Karena itulah, kita dapat memahami mengapa orang Timur yang telah mengunjungi kota-kota besar kita menganggap kebencian kita terhadap mereka sebagai hal yang ganjil dan paling tidak layak(2001:421-422).

Sesungguhnya, Islam tidak memulai poligami, tetapi membatasi jumlahnya dan pada waktu yang sama, menetapkan persyaratan yang tegas baginya. Di kalangan sebagian besar bangsa dan masyarakat yang menerima Islam, praktik ini adalah lumrah, dan atas perintah Islam mereka harus menyesuaikan diri dengan batas-batas dan persyaratan yang ditetapkan Islam.

Di samping itu, apabila penyebab poligami dituduhkan pada sistem patriarchy atau dominasi kaum pria, mengapa orang-orang Barat tidak menerapkannya? Bahkan, seorang Betrand Russel menyadari bahwa apabila monogami merupakan satu-satunya bentuk perkawinan yang sah, maka dengan sendirinya akan mengakibatkan kekosongan bagi sekelompok besar kaum wanita. Oleh karena itu, dalam Marriage and Morals, ia mengusulkan suatu pemecahan masalah, suatu pemecahan masalah yang sungguh-sungguh menakjubkan: yang sangat simpel dan sangat mudah. Kaum wanita yang kelebihan itu harus diizinkan memburu pria dan melahirkan anak haram, sehingga mereka tidak harus mengalami kekosongan, yakni kehilangan hak untuk memperoleh keturunan (dalam Muthahhari, 2001:235).

Itulah penyelesaian yang dikemukakan filsuf abad ke dua puluh atas problema sosial ini. Inilah penyelesaian yang diusulkan Islam. "Islam mengatakan, selesaikanlah masalah tersebut dengan cara ini, yaitu seorang pria yang mempunyai kelebihan secara finansial, moral, dan fisik yang dibutuhkan hendaklah mengambil tanggung jawab untuk menambah: lebih dari seorang wanita. Ia harus memberikan, kepada istri kedua itu kedudukan sebagai istrinya yang sah menurut agama ....... "(Muthahhari, 235-236).

Menurut Ali Syariati, banyak di antara para tokoh dan pembaharu dalam sejarah manusia yang gagal memperhatikan persoalan perempuan, atau bahkan meremehkannya sama sekali. Tetapi, Rasulallah saw adalah satu-satunya tokoh dan pembaharu besar yang sangat memperhatikan nasib kaum perempuan dan meninggikan harga diri serta hak-hak sosial mereka. Beliau memberikan jaminan Islam atas hak kepemilikan individu dan kebebasan ekonomi bagi kaum perempuan. Beliau mewajibkan laki-laki untuk memenhi seluruh kebutuhan material perempuan sampai dengan memberi hak untuk menuntut biaya perawatan anak-anak dan menentukan mahar perkawinan. 
Semua itu mengindikasikan adanya afirmasi atas jati diri dan hak-hak perempuan dalam Islam (Syariati, 2004:17).

Islam, lanjut Syariati, menilai diskriminasi sebagai kejahatan dan persamaan sebagai penyesatan. Peradaban (manusia) menentang yang pertama, dan kodrat alam menentang yang kedua. Dengan kata lain, Islam tidak menghendaki diskriminasi, tetapi juga tidak meyakini ide persamaan laki-laki dan perempuan. Apa yang ingin dicapai adalah menempatkan keduanya pada kedudukan alamiahnya masing-masing dalam suatu masyarakat.

Barangkali inilah beberapa bukti yang menunjukkan bahwa gugatan atas poligami tidak berdasar, dan kiranya bangsa ini harus belajar dari Barat dalam memandang wacana poligami. Inilah pendapat salah seorang guru di salah satu Universitas di Jerman:

Untuk menyelesaikan problematika perempuan di Jerman, terletak pada diperbolehkannya poligami, dan saya lebih senang untuk menjadi seorang istri bersama sepuluh istri lainnya bagi satu seorang lakilaki yang sukses, daripada menjadi istri tunggal bagi seorang laki-laki yang gagal. Sesungguhnya ini bukan pendapat saya semata akan tetapi pendapat seluruh perempuan di Jerman (Muhyiddin, 2006: 50).

Hal senada diungkapkan seorang aktivis wanita di London dalam "London Truth":

Banyak wanita yang mengalami depresi mental serta tekanan lainnya, sedangkan para cendekiawan Barat mengacuhkan problematika ini, jika aku melihat wanita seperti itu, hatiku bak disayat-sayat oleh sembilu, walaupun seluruh manusia hanyut dalam kedukaan, apakah kesedihanku ini ada harganya? Ternyata tidak ada manfaatnya sama sekali kecuali mencarikan solusi yang tepat untuk mencegah tragedi yang amat dahsyat. Hanya Allah-lah yang Maha Tahu lagi Maha Agung, Dia mengetahui suatu penyakit tapi Dia juga yangmengethui obatnya, yaitu memperbolehkan seorang laki-laki menikahi lebih dari satu wanita (poligami).dengan cara inilah,tragedi tersebut sirna, sehingga kita bisa menjadi suri di rumah.Petaka datang silih berganti karena otoritas lelaki Eropa yang hanya membolehkan beristri satu.

Monogami penyebab wanita kita mengalami depresi mental yang hebat, karena banyak dari wanita yang tidak mendapatkan porsi kasihsayang lelaki. Berpijak dari kasus ini, harus ada saling pengertian dengan membolehkan kaum adam berpoligami (dalam Abu Umar Basyir, 2007:130).

Eny Bezanet dalam bukunya "Al-Adyaan AlMunyasyirah fi al-Hind" mengatakan, Jika kita mau berpandangan secara obyektif pasti kita akan berkesimpulan, bahwa poligami dalam Islam merupakan terapi yang paling tepat daripada konsep Barat yang tolol itu, di mana banyak lelaki barat yang menjadikan wanita sebagai obyek pemuas nafsu semata, setelah mereka kenyang maka wanita tadi di lempar ke tengah jalan."

Di Amerika sendiri, tempat digaungkannya isu-isu kebebasan dan kesetaraan, oleh National Organization for Women of Utah, poligami diklaim sebagi 'gaya hidup terbaik kaum feminis'. Elizabeth, salah seorang pelaku poligami, pengacara dan jurnalis dalam salah satu pidatonya dalam konferensi "Menciptakan Dialog: Wanita Bicara pada Wanita", mengatakan:

"Saya sering menyatakan, seandainya poligami itu tidak ada, maka para wanita karier di Amerika yang akan mengadakannya. Sebab, di luar pandangan buruk yang ada, poligami adalah sebuah pilihan gaya hidup yang menawarkan ruang kesempatan yang nyata bagi para wanita karier untuk meraih semua impian (dalam Thalib, 2004:47-48).

Hal ini dimungkinkan mengingat wanita karier itu dapat terus menekuni kariernya, namun memperoleh rasa keibuan dengan menjadi ibu, dan kasih sayang dari suami yang menyayanginya. Juga, anak-anak dalam perkawinan poligami memperoleh naungan kasih sayang dan perlindungan dari keluarga besarnya manakala ibunya sibuk bekerja di luar. Dalam posisi seperti ini, menurut Elizabeth, wanita karier akan terlindungi dari rasa bersalah tidak sempat mengurus rumah tangga dan mengurus anak-anak, sebab anakanaknya ada dalam perlindungan orang dewasa yang menyayanginya, juga suaminya manakala dia tidak dapat sepenuhnya mengurus, akan tetap memperoleh perhatian dan pengurusan dari istrinya yang lain. 


\section{Kesimpulan}

Wacana secara ideologis dapat menggusur gagasan atau kelompok tertentu. Teks, karenanya dalam hal ini, telah menjadi sarana bagi satu kelompok dalam rangka mengunggulkan diri mereka sendiri dan pada saat yang bersamaan memarjinalkan kelompok lain. Bila dalam presentasi lazim dibahas bagaimana realitas atau objek ditampilkan di media massa. Karenanya menjadi sebuah konsekuensi logis bahwa di dalam presentasi ini terdapat kemungkinan apa yang disebut sebagai mispresentasi, sebuah realitas atau objek ditampilkan atau digambarkan tidak sebagaimana mestinya.

Bias adalah hal yang melekat dalam mispresentasi. Demikian pula halnya presentasi poligami di sebagian besar media elektronik di Indonesia mengandung bias, karena poligami digambarkan dalam bentuk mispresentasi. Wacana poligami dalam hal ini mengalami mispresentasi melalui strategi media massa dalam memilih aspek kebahasaan yang digunakan oleh narasumbernya yang cenderung memarjinalkan poligami dalam konteks wacana. Strategi stereotip dan labelisasi juga melekat dalam praktik mispresentasi wacana poligami di media massa ini.

\section{Daftar Pustaka}

Ahmad Jaiz Hartono, 2007, Wanita antara Jodoh, Poligami dan Perselingkuhan, Jakarta: Pustaka Al-Kautsar.

Aminuddin,dkk. 2002. Analisis Wacana: Dari Linguistik sampai Dekonstruksi. Yogyakarta: Kanal.
Bell Allan and Garret Peter. 1998. Approaches to Media Discourse. Massachussetts: Blackwell Publishers.

Eriyanto. 2001. Analisis Wacana, Yogyakarta: LKiS.

Eriyanto. 2002. Analisis Framing: Konstruksi Ideologi dan Politik Media. Yogyakarta: LKiS.

Mutahhari, Murtadha. 2001. Hak-hak wanita dalam Islam. Bandung: Mizan.

Syartiati, Ali. 2004. Mengapa Nabi Saw Berpoligami. Jakarta: Misbah.

Said Edward W., 2002, Covering Islam: Bagaimana Media dan Pakar Menetukan Cara Pandang Kita terhadap Dunia. Yogyakarta: Jendela.

Sobur, Alex. 2001. Analisis Teks Media; Suatu Pengantar untuk Analisis Wacana, Analisis Semiotik, dan Analisis Framing. Bandung: Remaja Rosda Karya.

Thalib, Muhammad. 2004. Orang Barat Bicara Poligami. Wihdah Press.

Usamah Muhyiddin Abu. 2006. Legalitas Poligami; Menurut Sudut Pandang Ajaran Islam. Yogyakarta: Sketsa.

Umar basyir Abu, 2007, Poligami Anugerah yang Terzhalimi, Solo: Rumah Dzikir.

Van Dijk, Teun A, 2003, ideology and Discourse : A Multidiciplinary Introduction, internet course for Oberta de Catalunya (VOC), ariel, Barcelona. 
